\title{
Adsorption of Mn(II) and Co(II) ions from aqueous solution using Maize cob activated carbon: Kinetics and Thermodynamics Studies
}

\section{${ }^{* 1}$ ADEBAYO, GB; ${ }^{2}$ ADEGOKE, HI; ${ }^{1}$ JAMIU, W; ${ }^{1}$ BALOGUN, BB; ${ }^{3} \mathrm{JIMOH} \mathrm{AA}$}

\author{
1Department of Industrial Chemistry, University of Ilorin, P.M.B 1515, Ilorin, Nigeria. \\ 2Department of Chemistry, University of Ilorin, P.M.B 1515, Ilorin, Nigeria. \\ 3Department of Chemistry, Kwara State University, Malete, Nigeria \\ Corresponding Author: waschem06@gmail.com. \\ Telephone: +2348063029504
}

\begin{abstract}
The adsorption of $\mathrm{Mn}(\mathrm{II})$ and $\mathrm{Co}(\mathrm{II})$ ions from aqueous solution was investigated using batch adsorption experiment at room temperature. The effect of $\mathrm{pH}$, contact time, metal ion concentration and temperature were evaluated. The residual concentrations of the metal ions were determined by atomic absorption spectrophotometer. The results showed that maximum removal of $\mathrm{Mn}$ (II) and $\mathrm{Co}(\mathrm{II})$ ions occurred at $\mathrm{pH} 9$. Some physico-chemical and spectroscopic characterization of the adsorbents were done such as moisture content, ash content, bulk density, volatile matter, iodine number, point of zero charge (PZC), XRF, and FTIR. The moisture and ash content of MCAC adsorbent were found to be $9.85 \pm 0.06$ and $5.5 \pm 0.1 \%$ respectively. The bulk density was found to be $0.37 \pm 0.01 \mathrm{~g} / \mathrm{m}^{3}$, iodine number of $367.66 \pm 30 \mathrm{mg} / \mathrm{g}$ and PZC of 6.8 . The SEM micrograph shows particle grains and jelly like rough surfaces, FTIR analysis results show different functional group in the $\mathrm{MCAB}$ adsorbent such as $\mathrm{O}-\mathrm{H}, \mathrm{C}=\mathrm{O}$, and $\mathrm{C}=\mathrm{C}$ stretching. Kinetic study shows that the pseudo-second order kinetic model best described the adsorption of metal ions. The equilibrium data fitted Langmuir, Freundlich and Temkin adsorption isotherms, in each case, the Langmuir model appears to have better regression coefficients than the Freundlich and Temkin. Thermodynamics investigation showed that Gibb's free energy change $(\Delta G)$ was negative indicating that the adsorption of $\mathrm{Mn}$ (II) and Co(II) ions by maize cob activated carbon were feasible and spontaneous. The positive value of enthalpy change $(\Delta \mathrm{H})$ implies that the reaction was endothermic while positive value of entropy change $(\Delta \mathrm{S})$ implies an irregular increase in the randomness at the solid/solution interface of the adsorbent during the adsorption process. C JASEM
\end{abstract}

\section{http://dx.doi.org/10.4314/jasem.v19i4.22}

KEY WORD: Adsorption, Heavy metals, Kinetics, Thermodynamics

\section{Introduction}

The increase in use of potentially toxic elements over the past few decades has unavoidably resulted in the flux of metallic substances in the aquatic and terrestrial environment (Jimoh et al., 2012). These metals once released through anthropogenic activities cannot be destroyed or degraded and thus persist indefinitely in the environment, accumulate in living tissues throughout the food chain and pose a serious menace to human and public health (Renuga et al., 2010).

Numerous concerted efforts have been made to remedy this occurrence, which includes the use of conventional methods such as ion exchange, membrane processing, electrolytic methods, chemical oxidation or chemical reduction, filtration, chemical precipitation and electrochemical treatment (Selvaraj et al., 2003). However, most of these methods are not economically feasible for small and medium size industries; they also suffered from high operational and maintenance costs, generation of toxic sludge and elaborated procedure involved in the wastewater treatment. Commercial activated carbon is unequivocally accepted as universal adsorbent for wastewater treatment, but due to its cost, developing country like Nigeria cannot avoid this treatment technique as consequence of low income per capital (Bhatnagar and Sillanp, 2010).

In addition, adsorption technique was considered better in wastewater treatment because of simplicity of design, convenience and ease of operation (Wasewar et al., 2009). In the past two decades, biosorption process has emerged as a cost effective and efficient alternative method for wastewater treatment utilizing naturally occurring agricultural waste materials as biosorbents. A large variety of agricultural wastes and by-products have been examined for their capability to remove pollutants from wastewater (Cay et al., 2011; Jimoh et al., 2012). Agricultural wastes are widely available, affordable and the presence of large amount of surface functional groups make agricultural wastes good alternatives to expensive synthetic adsorbents (Amarasinghe and Williams, 2007). 
Maize (Z. Mays) is the most widely grown grain crop throughout the West Africa and America. However, the cob is unutilized, thereby becoming an environmental nuisance. It is found to contain abundant functional groups, such as hydroxyl, amino and carbonyl groups which contain lone pairs of electrons needed for adsorption of cationic pollutants in solution (Babarinde et al., 2012a).

The main objective of this work is to convert waste to wealth by using maize cob, a readily agricultural waste for the removal of $\mathrm{Mn}(\mathrm{II})$ and $\mathrm{Co}(\mathrm{II})$ from aqueous solution.

\section{MATERIAS AND METHOD}

Sample preparation: The maize cob was obtained from Ipata market in Ilorin metropolis, Kwara state. The sample was sun dried for some days, it was later dried in an oven at $105^{\circ} \mathrm{C}$ overnight (Fan et al., 2003 and, Itodo et al., 2009) after which it was crushed using laboratory mortar and pestle, followed by sieving using smallest sieve size of $0.09 \mathrm{~mm}$. Five grams of the sieved sample was weighed into 10 different pre-weighed crucibles and it was introduced into the furnace at the temperature of $500^{\circ} \mathrm{C}$ for 20 minutes, the pyrolysed sample was cooled and ground into a granulated size and then activated with $\mathrm{H}_{3} \mathrm{PO}_{4}$ (Viboon et al., 2007). The char sample was mixed with $75 \%$ concentrated orthophosphoric acid in a beaker with the weight ratio of $\mathrm{H}_{3} \mathrm{PO}_{4} /$ char to be 0.1 . The slurry was evaporated at $60^{\circ} \mathrm{C}$ for 24 hours, and a dried mixture consisting of activated char and $\mathrm{H}_{3} \mathrm{PO}_{4}$ were obtained (Lillo- Rodenas et al., 2003). This was followed by washing to neutral $\mathrm{pH}$ of 7 (Viboon et al., 2007). The sample was then poured in a beaker containing $250 \mathrm{ml}$ of $0.1 \mathrm{M} \mathrm{HCl}$ for purification and stirred for 1 hour. Finally the sample was rinsed to a pH 6-7 (Strinivasan et al., 1999). The resulting activated carbon was kept in tightly closed container for application (Viboon et al., 2007).

Sample characterization: Fourier transform infrared spectroscopy (FTIR) spectra of maize cob activated carbon sample was obtained using a FTIR spectrophotometer (Model shimadzu 8400S) in wave number range of $3500-400 \mathrm{~cm}^{-1}$. The activated carbon sample was placed on a silicon substrate transparent to infrared, and the spectra were measured according to the transmittance method. The micrographs of prepared activated carbon were obtained using a JSM-7001F scanning electron microscopy.

Preparations of aqueous solutions : All chemicals (BDH, England) used in this study were of analytical reagent grade and were used without further purification. Standard solutions of $\mathrm{Mn}$ (II) and Co (II) used for the study were prepared from $\mathrm{MnCl}_{2} \cdot 4 \mathrm{H}_{2} \mathrm{O}$ and $\mathrm{CoCl}_{2} \cdot 6 \mathrm{H}_{2} \mathrm{O}$ respectively. The working solution with different concentrations of the metal ions was prepared by appropriate dilution of the stock solution immediately prior to their use with de-ionized water.

Adsorption procedure: Effect of initial metal ion concentration; Different concentrations of the adsorbate were prepared $(5,10,15,20,25$, and 30 $\mathrm{mg} / \mathrm{l})$ by serial dilution of the stock solution and then contacted with a fixed dosage of the adsorbent of $0.2 \mathrm{~g}$ and $25 \mathrm{ml}$ of the adsorbate in $100 \mathrm{ml}$ conical flask. It was then agitated for $2 \mathrm{hrs}$. At the end of time the mixture were filtered and analyzed using Atomic Absorption Spectrophotometer (210VGP model) (Jimoh et al., 2012).

Effect of Contact Time: The effect of contact time on metal adsorption was studied using metal ion concentration that gave optimal adsorption at different time intervals $(30,60,90,120,150$ and $180 \mathrm{~min}$ ). A $25 \mathrm{ml}$ of metal concentration (equilibrium concentration) of the adsorbate were contacted with $0.2 \mathrm{~g}$ dosage of the adsorbent, the mixture was well corked and were shaken using multi-purpose flask shaker for $2 \mathrm{hr}$. After completion of the reaction, conical flasks were taken out and resulting solution with adsorbent were filtered and analyzed using Atomic Absorption spectrophotometer (210VGP model) (Abdus-Salam and Itiola, 2012).

Effect of Adsorbent Dose: The metal ion concentration that gave optimal adsorption per $0.2 \mathrm{~g}$ was used. A $25 \mathrm{ml}$ of the adsorbate was contacted with varying amounts of the adsorbent doses (0.1, $0.2,0.3,0.4$, and 0.5$)$ grams at the equilibrium concentration (concentration of maximum adsorption). The mixture was agitated with an orbital mechanical shaker for $2 \mathrm{hr}$. The resultant solution with the adsorbent in the flask was filtered and the filtrates were analyzed using Atomic Absorption Spectrophotometer (AAS). This will enable us to see the exact adsorbent dose which will be sufficient for optimal removal of the metals (210VGP model) (Abdus-salam and Itiola, 2012).

Effect of pH: A $25 \mathrm{ml}$ of the optimum (equilibrium) concentration for $\mathrm{Co}$ (II) were contacted with $0.2 \mathrm{~g}$ of the adsorbent in a $100 \mathrm{ml}$ conical flask and the $\mathrm{pH}$ of the solution matrix was varied with $0.1 \mathrm{M} \mathrm{HCl}$ and $0.1 \mathrm{M} \mathrm{NaOH}$ to obtained $\mathrm{pH}$ of $3,5,7,9$ and 11 .The solution were equilibrated for $2 \mathrm{hr}$, filtered and the residual metal ion concentrations were analyzed using Atomic Absorption Spectrophotometer (210VGP model) (Elaigwu et al., 2009).

Effect of Temperature: The Temperature was varied between 30 and $70^{\circ} \mathrm{C}$ i.e. $\left(30,40,50,60\right.$ and 70) ${ }^{\circ} \mathrm{C}$. A $25 \mathrm{ml}$ of the optimum concentration for Co (II) were contacted with $0.2 \mathrm{~g}$ of the adsorbent in a $100 \mathrm{ml}$ conical flask. The mixtures were equilibrated for $2 \mathrm{hr}$ at stated temperatures. The flask were then brought out and filtered. The filtrates were analyzed using 
Atomic Absorption Spectrophotometer (210VGP model) (Abdus-Salam and Itiola, 2012). The amount of metal ion adsorbed by the acid modified and activated carbon was calculated by using the following equation $\mathrm{Q}_{\mathrm{e}}=\frac{V\left(C_{0}-C_{e}\right)}{M}$ (1) Where $q_{\mathrm{e}}$ is the quantity adsorbed $(\mathrm{mg} / \mathrm{L}), C_{\mathrm{o}}$ and $C_{\mathrm{e}}$ are the initial and final concentration of metal ion in solution at any time, $\mathrm{t}(\mathrm{mg} / \mathrm{L}), V$ is the total volume of the metal standard solution in the flask (L), $\mathrm{M}$ is the mass of adsorbent used (g) (Ajmal et al., 2000)

\section{RESULTS AND DISCUSSION}

Physico-chemical and spectroscopic characterization of the activated carbon sample

Table 1: Physico-chemical properties of adsorbent prepared from maize cob

\begin{tabular}{ll}
\hline Properties & Activated carbon \\
\hline Moisture content $(\%)$ & $9.85 \pm 0.06$ \\
& \\
Ash content $(\%)$ & $5.5 \pm 0.1$ \\
Bulk density $\left(\mathrm{g} / \mathrm{m}^{3}\right)$ & $0.37 \pm 0.01$ \\
Yield $(\%)$ & $72.50 \pm 0.01$ \\
Volatile matter $(\%)$ & $22.21 \pm 1.0$ \\
Point of zero charge & 6.8 \\
Iodine number $(\mathrm{mg} / \mathrm{g})$ & $367.66 \pm 30$ \\
\hline
\end{tabular}

Moisture content is the amount of water retained by the sample and suggests extensive porosity in the structure of all adsorbents. Although, moisture content of the activated carbon has no effect on its adsorptive power, it has been observed that if the moisture content of adsorbent is high its adsorptive capacity will be reduced and it would necessitate utilizing an additional weight of the carbon during treatment process. (Sugunadevi et al., 2002). The moisture content of the activated carbon was $9.85 \pm 0.06 \%$, higher than the value reported elsewhere Mane et al., 2005, (9.7\%), and Salman et al., 2011, $(4.5 \%)$

The ash content shows the amount of inorganic constituents associated with carbon. Ash content of adsorbents usually increases with increase in carbonization temperature. This was believed to be due to lowered volatile matter (Gan et al., 2004). The percentage ash contents for the adsorbent obtained was $5.5 \pm 0.1 \%$, lower than the value of adsorbents reported by Salman et al., 2011, (10.5\%), Aloko and Adebayo, 2008, (29.24) and close to the value reported elsewhere, Mane et al., 2005, (5.6\%) and Elnasri et al., 2013, (5.9\%). The ash content of adsorbents increased with decreased percentage of volatile matter which indicates that ash is non-volatile as reported (Gan et al., 2004).

Bulk density indicates the fiber content of the precursor. It is an important parameter when carbon is removed by filtration, because it determines the quantity of carbons that is contained in a filter of a given solid capacity and how much treated liquid is retained by the filter cake. Carbons with adequate density also help to improve the filtration rate by forming an even cake on the filter surface. Activated carbon adsorbent density is $0.37 \pm 0.01$, which was lower than the value reported by Itodo et al., 2011, $\left(0.53 \mathrm{~g} / \mathrm{m}^{3}\right)$, Onundi et al., 2011, $\left(0.864 \mathrm{~g} / \mathrm{m}^{3}\right)$, the value was moderate when compared with literature values. Generally, an adsorbent with high bulk density need not be regenerated frequently because it can hold more adsorbate per unit weight (Yang and Lua., 2003).

The percentage yield obtained for the activated carbon adsorbent is $72.50 \pm 0.01 \%$. This is an indication of high percentage yield compared to the reported percentage yield of $51 \%$ by Faust and Aly, (1983); Sahu et al., 2010, (46.08\%). The activated carbon adsorbent obtained have good percentage yield, Ash content and volatile matter than the acid modified adsorbent as reported elsewhere, Raffiea $e t$ al., 2012.

Volatile matter is due to the presence of organic compounds present in the raw material. It was evident that at longer carbonization period, more volatiles are released from the char, thereby resulting to a higher burn off and a corresponding lower yield (Itodo et al., 2011). The volatile matter obtained for the activated carbon adsorbent was $22.21 \pm 1.0 \%$, which is higher than the value reported by Raffiea et al., 2012 $(20.9 \%)$.

The Point of Zero Charge (PZC) is a phenomenon of adsorption, and it describes the condition when the electronic charge density on a surface is zero (Kirby 2010). The PZC is located at the point of interception of the curves when traced to the $\mathrm{pH}$ axis. The PZC is (usually) the $\mathrm{pH}$ value at which a solid submerged in an electrolyte exhibit zero net electronic charge on the surface. The pHpzc of the adsorbent is 6.8 which are lower than the value reported elsewhere by Elnasri et al., 2013 (7.3).

The Iodine number is the most fundamental parameter used to characterize activated carbon performance. It is measure of activity level of the adsorbent, the higher the iodine number, the higher the degree of activation and the development of the microporous structure (Raffiea et al., 2012). It is often reported in $\mathrm{mg} / \mathrm{g}$. The iodine number of the activated carbon adsorbent is $367.66 \pm 30 \mathrm{mg} / \mathrm{g}$, which is lower than the one reported by Raffiea et al., 2012, (798 mg/g).

The surface morphology of the activated carbon was analyzed by scanning electron microscopy (SEM), the corresponding SEM micrographs being obtained at 1000 and 10000 magnifications as shown in 
Figures 1 and 2. The micrographs revealed particle grains and jelly like rough surface area which generally believe to be a good requirement for the adsorptive properties. It can be clearly seen that chemical activation resulted in a porous structure and the opening of pores on the surface of activated

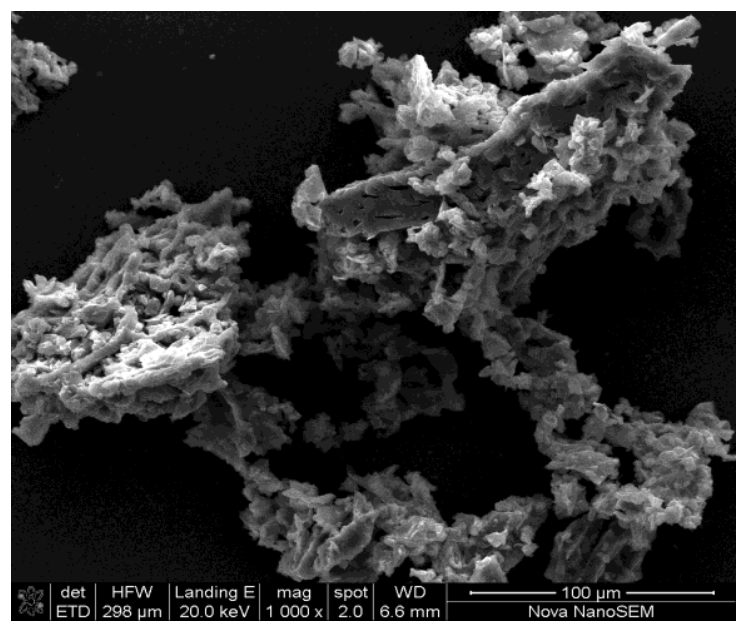

Fig. 1 (SEM micrograph for activated carbon at $1 \mathrm{kx}$ )

The chemical structure of the adsorbent is of vital importance in understanding the adsorption process. The FTIR technique is an important tool to identify the characteristic functional groups, which are instrumental in adsorption process (Das and Mondal, 2011). The FTIR spectrum of the maize cob activated carbon was used to determine the vibrational frequency changes in the functional groups in the adsorbent. As seen in Fig.3, the adsorption peak around $3410.26 \mathrm{~cm}^{-1}$ indicates the existence of free hydroxyl groups, the $\mathrm{C}-\mathrm{H}$ stretching vibration around carbon as reported elsewhere (Deng et al., 2010). It is generally observed that pore structure development is influenced by many factors, such as inorganic impurities and the initial structure of the carbon precursor (Deng et al., 2010).

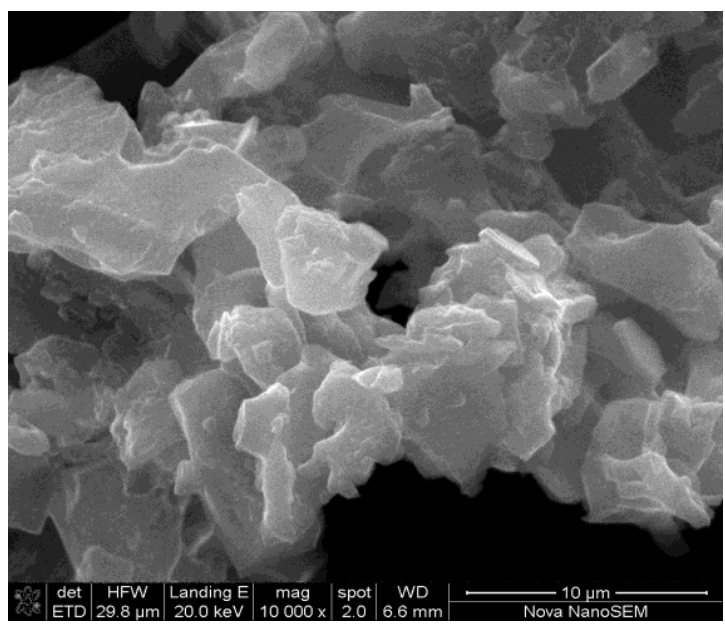

Fig. 2 (SEM Micrograph for activated carbon at 10kx)

$2906.82 \mathrm{~cm}^{-1}$ indicate the presence of alkanes. The peaks around $1693.56 \mathrm{~cm}^{-1}$ corresponds to the $\mathrm{C}=\mathrm{O}$ stretching that may be attributed to the hemicelluloses and lignin aromatic groups (Deng et al., 2010).The $\mathrm{C}=\mathrm{C}$ stretching vibrations around $1593.25 \mathrm{~cm}-1$ indicative of alkenes and aromatic functional groups. The peaks in the $1141.90 \mathrm{~cm}^{-1}$ corresponds to vibration of $\mathrm{CO}$ group in lactones. Some week bands were also observed in the range of $600-700 \mathrm{~cm}^{-1}$, indicating the presence of $\mathrm{C}-\mathrm{C}$ stretching

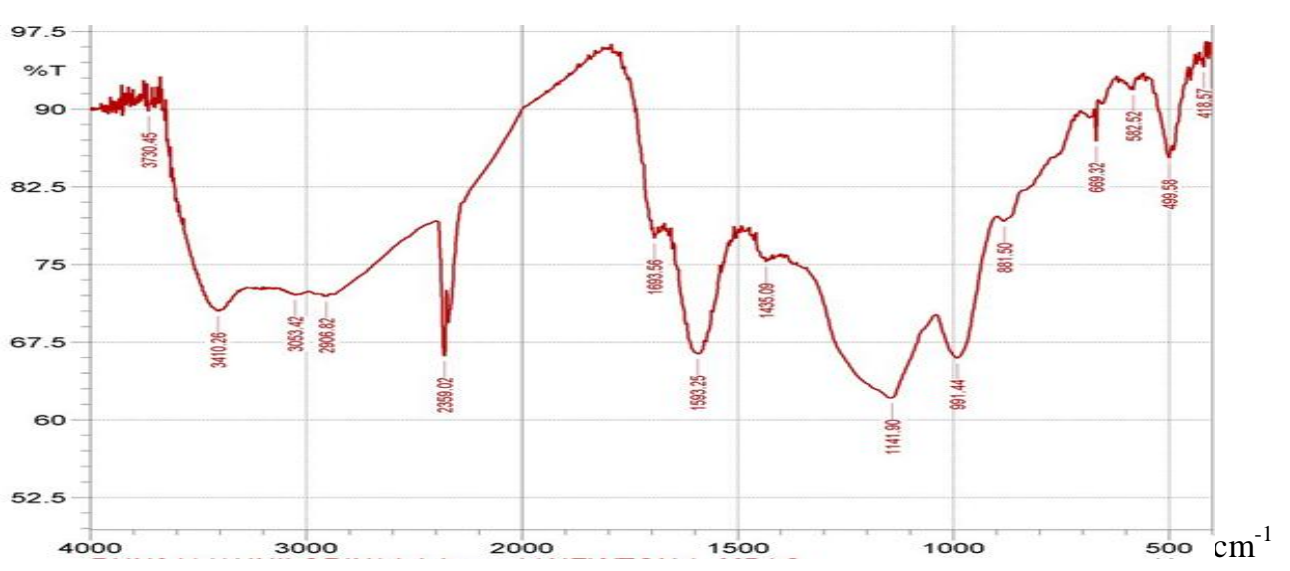

Fig. 3. FTIR spectrum for the activated carbon

Adsorption experiment results: Effect of Initial Concentration: The adsorption of metal ions by an adsorbent is strongly dependent on the initial concentration of metal ions in solution. It can be seen that as initial concentration of metal ions were increased from $5 \mathrm{ppm}$ to $30 \mathrm{ppm}$, corresponding increase in the adsorption capacities also occurred until the maximum adsorption attained at initial concentration of $20 \mathrm{ppm}$ after which the adsorption decreases. The actual amount of Mn (II) and Co (II) 
ions adsorbed per unit mass of activated carbon increased with increase in metal ion concentration. It has been reported that as the metal ion concentration is increasing, more ions are available for adsorption on the adsorbent (Adegoke et al., 2014). The rapid increase in the rate of adsorption have also been attributed to the sufficient surface area to accommodate more metal available in the solution due to the effect of concentration gradient which is the main driving force for the adsorption process (Mishra et al., 2009). The results obtained corroborated the findings of Okeimen and Onyenkpa (2000) and Elaigwu et al. (2009) that as the concentration of the adsorbate increase, the metal ions removed also increase.

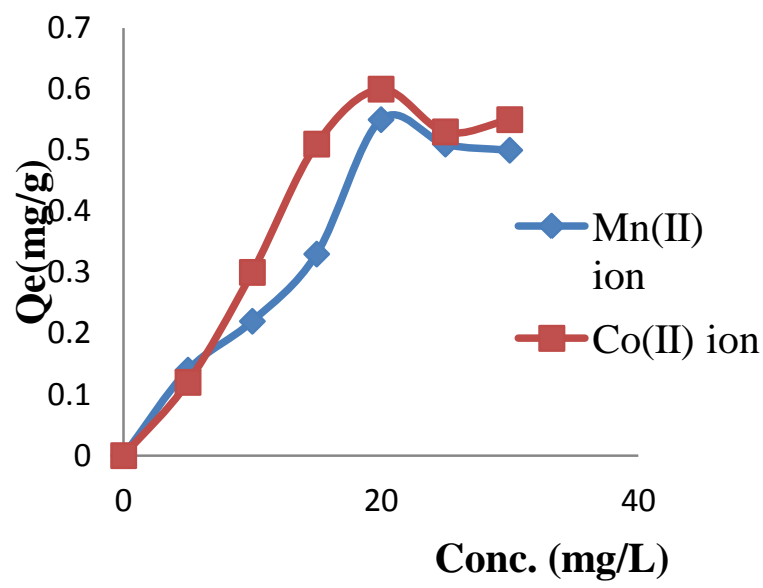

Fig 4. Effect of initial metal ions concentration on the adsorption of $\mathrm{Mn}$ (II) and $\mathrm{Co}$ (II) ion by Maize cob activated carbon

Effect of Contact Time: The adsorption of metal ions from aqueous solution is controlled by the rate of reaction which determines the equilibrium time. It is one of the important characteristics defining the efficiency of an adsorbent (Krishnan and Anirudhan, 2003). The time of the adsorbent-adsorbate is of great importance in adsorption, because it depends on the nature of the system used. The effects of agitation time for the adsorption of $\mathrm{Mn}(\mathrm{II})$ and $\mathrm{Co}(\mathrm{II})$ ions were studied between 30 and 180minutes. Maize cob activated carbon sample had maximum adsorption capacity within 120 minutes of the experiment; further increase in contact time had no significant effect on the adsorption capacity. The maximum adsorption capacity observed at 120 minutes of contact time may be due to large number of vacant sites available, which later slowed down and may be attributed to exhaustion of remaining surface sites and repulsive force between the adsorbent and metal ions

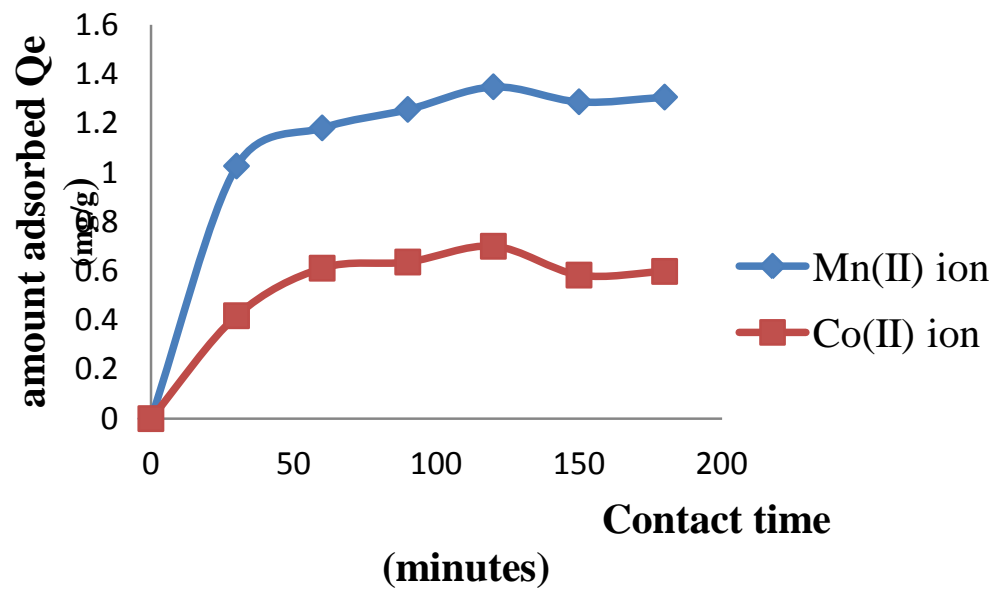

Fig 5. Effect of contact time on the adsorption of $\mathrm{Mn}(\mathrm{II})$ and $\mathrm{Co}(\mathrm{II})$ onto maize cob activated carbon

Effect of $\mathrm{pH}$ : The initial $\mathrm{pH}$ of a solution is a very important factor to be considered in adsorption studies as it has been observed to play a major role in the adsorption of metal ions by various adsorbents, because it affects the solubility of the metal ions, concentration of the counter ions on the functional groups of the adsorbent and the degree of ionization of the adsorbate during reaction (Badmus et al., 2007; Sheng et al., 2004). The effect of $\mathrm{pH}$ on the $\mathrm{Mn}(\mathrm{II})$ and $\mathrm{Co}$ (II) ions adsorption capacities of maize cob 
adsorbent was conducted at various $\mathrm{pH}$ ranging 3-11 with $20 \mathrm{mg} / \mathrm{L}$ fixed initial metal ion concentrations and contact time of 2 hours. The result shows that the maximum adsorption was observed at $\mathrm{pH} 9$ for both metal ions, it can be seen that the amount adsorbed increases with increases in $\mathrm{pH}$. Similar trend were reported in literature elsewhere (Kobya et al., 2005).

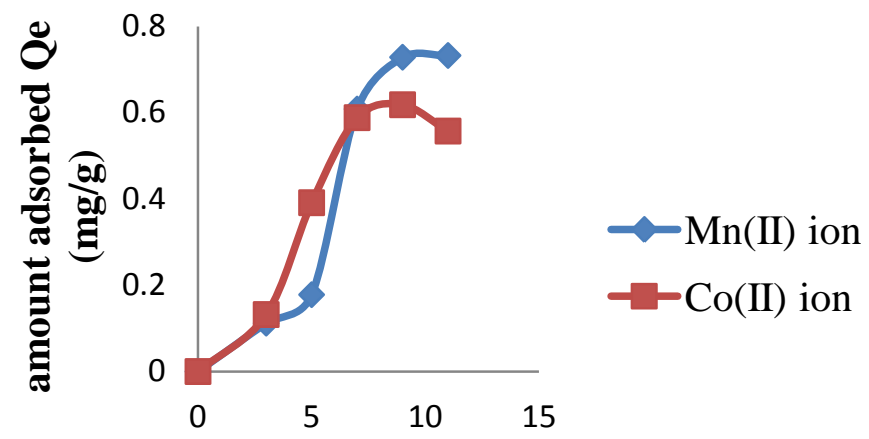

pH

Fig. 6. Effect of $\mathrm{pH}$ on the sorption of $\mathrm{Mn}(\mathrm{II})$ and $\mathrm{Co}(\mathrm{II})$ onto maize cob adsorbent

Effect of Adsorbent dose: The influence of different amounts of adsorbents dose $0.1-0.5 \mathrm{~g}$ on $\mathrm{Mn}(\mathrm{II})$ and $\mathrm{Co}$ (II) ions adsorption at constant initial metal ion concentration of $20 \mathrm{mg} / \mathrm{L}$, contact time of 2 hours and the temperature of $298 \mathrm{~K}$, showed decrease in the quantity adsorbed with increase in adsorbent dosage rate as the number of sorbate ions concentration decreases per active site available for sorption on the surface (Yu et al., 2000). The effect of adsorbent dose on adsorption of $\mathrm{Mn}$ (II) and $\mathrm{Co}$ (II) ions on maize cob adsorbent, and maximum adsorption was observed at $0.1 \mathrm{~g}$ for maize cob adsorbents. The observation shows that small amount of adsorbent gave maximum adsorption; this may be due to the high surface area and micropore volume of the sample (Babarinde et al., 2012a).

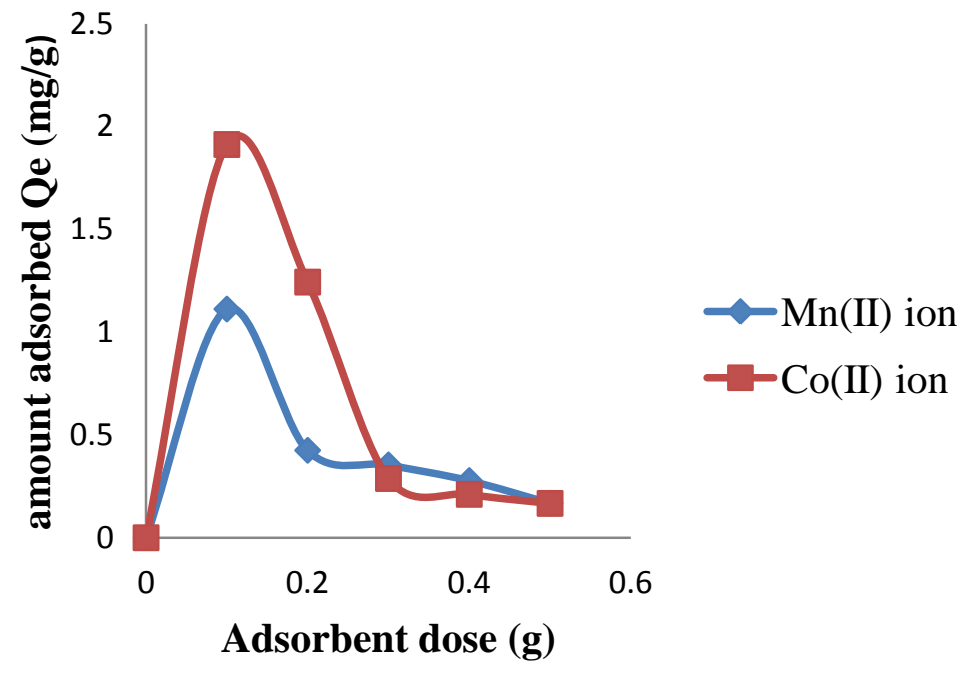

Fig 7. Effect of adsorbent dose on the adsorption of $\mathrm{Mn}$ (II) and $\mathrm{Co}$ (II) onto maize cob activated carbon

Effect of Temperature: The study showed that there was gradual increase in the removal efficiency for all the metal ions as temperature increases from 303 to $343 \mathrm{~K}$. The increase in the amount of metal ions adsorbed as temperature increases might be attributed to the fact that the adsorption by maize cob adsorbent may involve not only physical but also chemical adsorption, and sometimes may also involve bond rupture (Jimoh et al., 2013). From the result obtained, it can be seen that the number of adsorption sites tend to increase with increase in temperature which may be an indication of possible chemical interactions between the adsorbate and the adsorbent (Ekop and Eddy, 2010). 


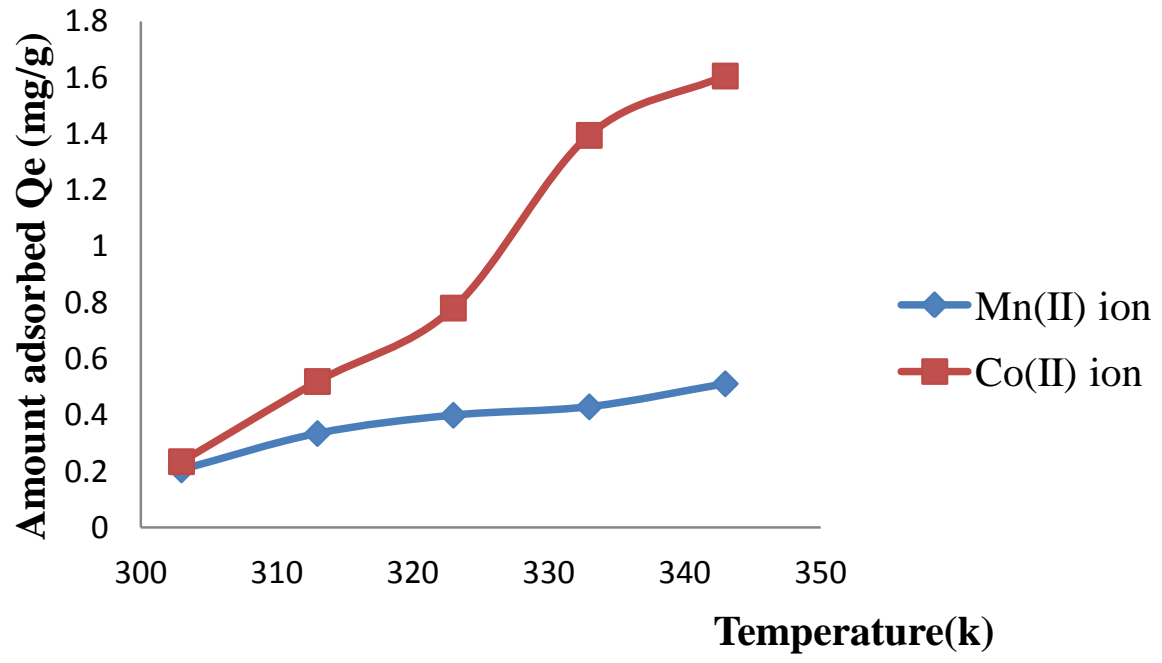

Fig 8. Effect of temperature on the sorption of $\mathrm{Mn}(\mathrm{II})$ and $\mathrm{Co}(\mathrm{II})$ ions onto maize cob adsorbent.

Adsorption isotherms: Three adsorption isotherms were employed on the experimental data obtained in this research work and their respective formula are given below. (i) Langmuir adsorption isotherm, Langmuir adsorption isotherm equation is given below:

$\frac{C e}{q_{e}}=\frac{1}{K_{L} q_{\max }}+\frac{C_{e}}{q_{\max }} \quad$ (2) where $C e$ is the equilibrium concentration $(\mathrm{mg} / \mathrm{L}), q_{e}$ is the amount adsorbed at equilibrium $(\mathrm{mg} / \mathrm{g}), q_{\max }$ is the maximum amount of adsorption with complete monolayer coverage on the adsorbent surface $(\mathrm{mg} / \mathrm{g})$ and $K_{L}$ is the Langmuir constant (L/mg) (Langmuir, 1918). (ii) Freundlich adsorption isotherm

Freundlich isotherm is the earliest known relationship describing the adsorption equation and is often expressed as $\log q_{e}=\log k_{f}+\frac{1}{n} \log C_{e}$

Where Qe is the quantity of solute adsorbed at equilibrium (adsorption density: mg of adsorbate per $\mathrm{g}$ of adsorbent). $\mathrm{C}_{\mathrm{e}}$ is the concentration of adsorbate at equilibrium, $\mathrm{K}_{\mathrm{f}}$ and $\mathrm{n}$ are the empirical constants dependent on several factors and $\mathrm{n}$ is greater than one. (Najua et al., 2008)

(iii) Temkim isotherm Temkim isotherm is given by the following equation: $\quad Q_{e}=\frac{R T}{b} \ln K_{T} C_{e}$ Equation above can be linearized into the following:: $Q_{e}=B \ln K_{T}+B \ln C_{e} \quad$ (5) where $B=\frac{R T}{b}$

Regression of $\mathrm{q}_{\mathrm{e}}$ against $\ln _{\mathrm{e}}$ enables the determination of isotherm constant $\mathrm{K}_{\mathrm{T}}$ and $\mathrm{B}$. The $\mathrm{K}_{\mathrm{T}}$ is the equilibrium binding constant ( $\mathrm{L} / \mathrm{mg})$ corresponding to maximum binding energy and constant is related to the heat of adsorption.

The Langmuir isotherm plots are presented in Figure $9 \& 10$. The various parameters are shown in Tables 2. From Table 2, the adsorption of $\mathrm{Mn}$ (II) and $\mathrm{Co}$ (II) ions onto maize cob activated carbon can best be described by Langmuir isotherm based on the correlation coefficient values and other constant parameters obtained. This means that the adsorption of the metal ions onto maize cob activated carbon was physical, heterogenous and multilayer in nature (Najua et al., 2008). The parameters of the Langmuir isotherms show that Langmuir isotherm model is a better isotherm than the Freundlich and Temkin model as represented in Table 2. The order of fitness was Langmuir> Freundlich > Temkin. This is similar to the obtained results by (Jimoh et al. 2011 and Wasewar et al. 2009).

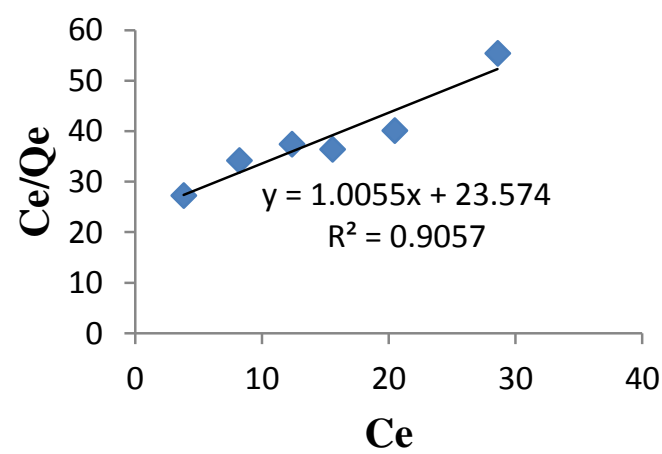

Fig 9. Langmuir plot tor Mn(II) onto Maize cob adsorbent

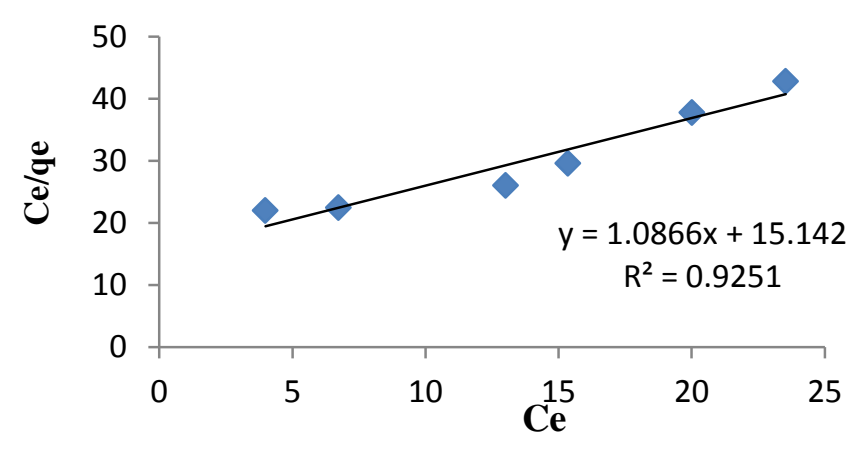

Fig 10: Langmuir plot of $\mathrm{Co}(\mathrm{II})$ onto Maize cob adsorbent 
Table2. Langmuir, Freundlich and Temkin isotherm parameters for the adsorption of

\begin{tabular}{|c|c|c|c|c|c|c|}
\hline Metal ion & \multirow{2}{*}{\begin{tabular}{ll}
\multicolumn{2}{l}{ Langmuir parameters } \\
$\mathrm{q}_{\max } \mathrm{K}_{\mathrm{L}}$ & $\mathrm{R}^{2}$ \\
$(\mathrm{mg} / \mathrm{g})$ & $(\mathrm{L} / \mathrm{mg})$
\end{tabular}} & \multicolumn{3}{|c|}{ Freundlich parameters } & \multicolumn{2}{|c|}{ Temkin parameters } \\
\hline \multirow{3}{*}{$\begin{array}{l}\operatorname{Mn}(I I) \\
\operatorname{Co}(I I)\end{array}$} & & $\begin{array}{l}\mathrm{K}_{\mathrm{f}} \\
(\mathrm{mg} / \mathrm{g})\end{array}$ & & $\begin{array}{ll}n & R^{2}\end{array}$ & $\begin{array}{l}\text { B } \\
(\mathrm{Kj} / \mathrm{mol}) \quad(\mathrm{L} / \mathrm{mg})\end{array}$ & $\mathrm{K}_{\mathrm{T}}$ \\
\hline & $\begin{array}{llll}0.930 & 0.045 & 0.915\end{array}$ & 0.054 & 0.726 & 0.887 & $0.179 \quad 1.094$ & 0.679 \\
\hline & $\begin{array}{lll}0.920 & 0.071 & 0.925\end{array}$ & 0.048 & 0.843 & 0.864 & 0.256 & 0.256 \\
\hline
\end{tabular}

Adsorption kinetics: In analysis of the kinetics profile of this sorbent material, pseudo-first, pseudo-second order and Elovich kinetics model were employed and the equations are stated as follows.

(i) Pseudo-first order kinetics: The rate law is given below: $\frac{d q_{t}}{d t}=k_{1}\left(q_{e}-q_{t}\right)$ (6) Where, $\mathrm{q}_{\mathrm{e}}$ and $\mathrm{q}_{\mathrm{t}}$ are the amount of $\mathrm{Co}$ (II) adsorbed at equilibrium and time $t$, respectively. $\mathrm{K}_{1}$ is the rate constant for the pseudo first order adsorption. The integrated law is given as follows: $\log \left(q_{e}-q_{t}\right)=\log q_{e}-\frac{K}{2.303}$

A plot of $\log \left(q_{e}-q_{t}\right)$ against $t$ was made and the values of $\mathrm{k}_{1}$ and $\mathrm{q}_{\mathrm{e}}$ were obtained from the slope and intercept, respectively (Ho and Mckay, 2000). (ii) Pseudo-second order kinetics: The linear form of pseudo-second order kinetics model is given as: $\frac{t}{q_{t}}=\frac{1}{k_{2} q_{e}^{2}}+\frac{1}{q_{e}} t \quad$ (8) Where, $\mathrm{q}_{\mathrm{e}}$ and $q_{t}$ are the amount of metal ion adsorbed per unit mass of the adsorbent (in $\mathrm{mg} \mathrm{g}^{-1}$ ) at equilibrium and time $t$, respectively, and $k_{2}$ is the pseudo second order rate constant. A linear plot of $\mathrm{t} / \mathrm{q}_{\mathrm{t}}$ against $t$ confirms the fitness of data to this model (Ho and Mckay, 2000) (iii) The Elovich Model

The Elovich model equation is generally expressed as: $q_{t}=\frac{1}{\beta} \ln (\alpha \beta)+\frac{1}{\beta} \ln (t)$
Where $\alpha$ is the initial adsorption rate $\left(\mathrm{mg} \cdot \mathrm{g}^{-1} \mathrm{~min}^{-1}\right)$. $\beta$ is the desorption constant (g.mg ${ }^{-1}$ ) during any experiment. If the adsorption process fits the Elovich model, a plot of $\mathrm{q}_{\mathrm{t}}$ against $\ln (\mathrm{t})$ should yield a linear relationship with a slope of $\left(\frac{1}{\beta}\right)$ and an intercept of $\left(\frac{1}{\beta}\right) \ln (\alpha \beta)$. The conformity between experimented data and the model- predicted values was expressed by the correlation coefficients $\left(\mathrm{R}^{2}\right.$, value close or equal to 1 ). A relatively high $\mathrm{R}^{2}$ value indicates that the model successfully describes the adsorption kinetics (Chien and Clayton, 1980; Sparks, 1986).

The kinetics of an adsorption is probably the most important factor in predicting the rate at which adsorption takes place for a given system. Three kinetic models were employed. These are the pseudofirst order, the pseudo-second order and the Elovich equations. The models were examined for suitability using their correlation coefficient, $\mathrm{R}^{2}$ as reported elsewhere (Jimoh et al., 2013). Our result revealed that the adsorption of the metal ions could be best explained using the pseudo-second order. This was due to the higher correlation regression coefficient $\mathrm{R}^{2}$ value. This trend was the same as reported elsewhere (Idris et al., 2012). The pseudo second order plots were presented in figure 11 , and the parameters are shown in Table 3.

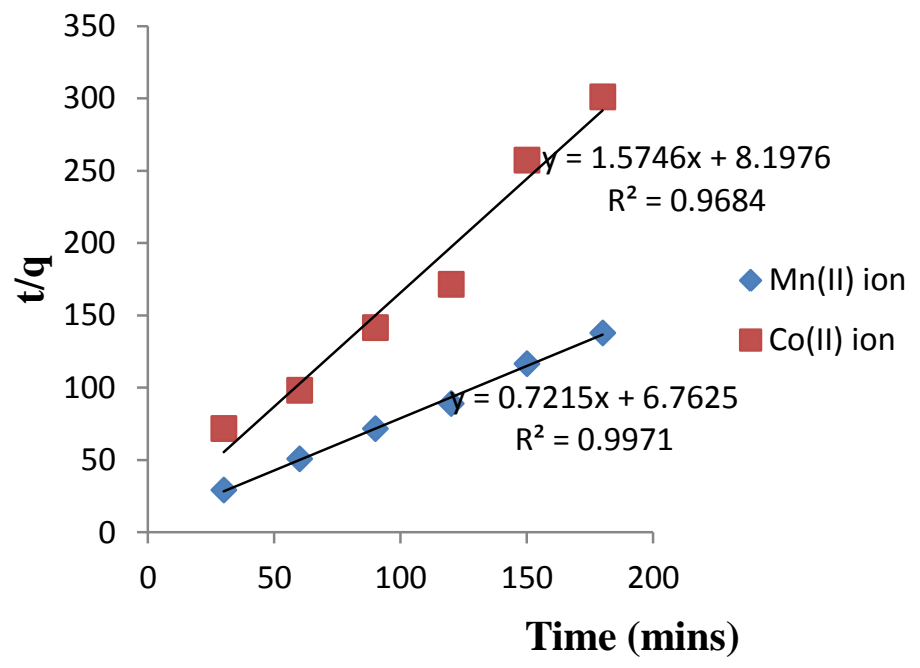

Fig 11. Pseudo-second order plot for adsorption of $\mathrm{Mn}$ (II) and $\mathrm{Co}(\mathrm{II})$ onto maize cob activated carbon. 
Table 3. Parameters of the Pseudo-second order kinetic model for the adsorption of Mn(II) and Co(II) ions by maize cob activated carbon.

\begin{tabular}{lcccc}
\hline \multicolumn{2}{l}{ pseudo second-order } & \multicolumn{2}{c}{ parameters } \\
\hline $\mathbf{K}_{\mathbf{2}}\left(\mathbf{g m g}^{-1} \mathbf{m i n}^{-1}\right)$ & $\mathrm{q}_{\mathrm{e}}\left(\mathrm{mgg}^{-1}\right)$ & & $\mathrm{R}^{2}$ & \\
$\mathbf{M n}(\mathbf{I I})$ & 0.076 & 1.386 & & 0.997 \\
Co(II) & 0.302 & 0.635 & & 0.968 \\
\end{tabular}

Adsorption thermodynamics: The thermodynamics parameters such as Gibbs free energy change $(\Delta \mathrm{G})$, enthalpy change $(\Delta \mathrm{H})$ and entropy change $(\Delta \mathrm{S})$ were also studied in order to understand better the effect of temperature on the adsorption of $\mathrm{Co}(\mathrm{II})$ ions. The Gibb's free energy change $(\Delta G)$ is related to the thermodynamics equilibrium constant by the following equation:

$$
\begin{gathered}
K_{c}=\frac{C_{A_{e}}}{C_{e}} \quad \text { (10) } \Delta G^{0}=-R T \ln K_{C} \\
\text { (11) } \log K_{C}=\frac{\Delta S}{2.303 R}-\frac{\Delta H}{2.303 R T}
\end{gathered}
$$

Where, $\mathrm{K}_{\mathrm{c}}$ is the equilibrium constant, $\mathrm{C}_{\mathrm{e}}$ is the equilibrium concentration in solution $(\mathrm{mg} / \mathrm{L})$ and $\mathrm{C}_{\mathrm{Ae}}$ is the solid-phase concentration at equilibrium $(\mathrm{mg} / \mathrm{L}) ., \Delta \mathrm{G}, \Delta \mathrm{H}$ and $\Delta \mathrm{S}$ are changes in Gibbs free energy $(\mathrm{kJ} / \mathrm{mol})$, enthalpy $(\mathrm{kJ} / \mathrm{mol})$ and entropy $(\mathrm{J} / \mathrm{mol} / \mathrm{K})$, respectively. $\mathrm{R}$ is the gas constant $(8.314$ $\mathrm{J} / \mathrm{mol} / \mathrm{K})$ and $\mathrm{T}$ is the temperature $(\mathrm{K})$. The values of $\Delta \mathrm{H}$ and $\Delta \mathrm{S}$ was determined from the slope and the intercept of Van't Hoff plots of $\log K_{c}$ versus $1 / T$ (Mohan and Singh, 2002).
From Table 4, it could be observed that enthalpy change $(\Delta \mathrm{H})$ and entropy change $(\Delta \mathrm{S})$ was positive for all the metals ions while Gibb's free energy change $(\Delta G)$ were negative in the same way. The negative values of Gibb's free energy change $(\Delta G)$ at all temperatures examined indicates that the adsorption of $\mathrm{Mn}$ (II) and $\mathrm{Co}$ (II) ions by maize cob was feasible and correspond to a spontaneous physical adsorption of the metal ions, which indicate that this adsorption process does not gain external energy (Vimonses et al., 2009). The positive values of enthalpy change $(\Delta \mathrm{H})$ revealed that the adsorption process was endothermic and non-physical in nature. Furthermore, positive values of entropy change $(\Delta S)$ was an indication of an irregular increase in the degree of the randomness at the adsorbent-adsorbate interface during the adsorption. The order of spontaneity of the biosorption process was found to be $\mathrm{Mn}$ (II) < $\mathrm{Co}$ (II) which was contrary to the findings reported for the biosorption of these metal ions with banana leaf by Babarinde et al. (2012b).

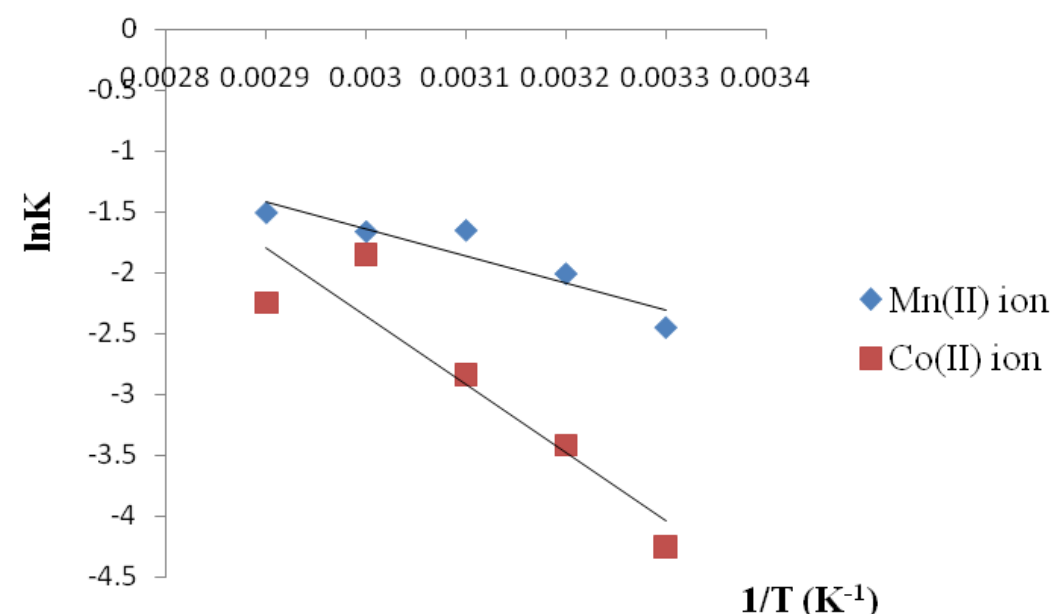

Fig 12. Thermodynamic plots for the adsorption of $\mathrm{Mn}$ (II) and $\mathrm{Co}$ (II) by maize cob activated carbon.

Table 4. Thermodynamic parameters for the adsorption of $\mathrm{Mn}$ (II) and $\mathrm{Co}(\mathrm{II})$ by maize cob activated carbon

\begin{tabular}{lllllclc}
\hline \multicolumn{2}{l}{ Metal ion } & $\Delta \mathbf{H}$ & \multicolumn{1}{c}{$\Delta \mathbf{S}$} & \multicolumn{3}{c}{$\Delta \mathbf{G}(\mathrm{KJ} / \mathrm{mol})$} \\
\hline & $\mathrm{KJ} / \mathrm{mol}$ & $\mathrm{J} / \mathrm{mol} / \mathrm{K}$ & $303 \mathrm{~K}$ & $313 \mathrm{~K}$ & $323 \mathrm{~K}$ & $333 \mathrm{~K}$ & $343 \mathrm{~K}$ \\
$\mathrm{Mn}(\mathrm{II})$ & +16.803 & +20.502 & -6.195 & --6.400 & -6.605 & 6.810 & 7.015 \\
$\mathrm{Co}(\mathrm{II})$ & +46.475 & +119.805 & 36.254 & -37.452 & 38.650 & 39.848 & 41.046 \\
\hline
\end{tabular}

Conclusion: Based on the above study the following conclusions were drawn: (i) $\mathrm{pH}$, contact time, metal ions concentration and temperature had a remarkable effect on the metal uptake level by the substrate. (ii) The biosorption process of the metal ions was best described by a pseudo-second order. (iii) The 
equilibrium data could be best explained by Langmuir than Freundlich and Temkin isotherm. (iv) Thermodynamics investigation showed that Gibb's free energy change $(\Delta \mathrm{G})$ was negative indicating that the adsorption of $\mathrm{Mn}$ (II) and $\mathrm{Co}$ (II) ions by maize cob activated carbon were feasible and spontaneous. The positive value of enthalpy change $(\Delta \mathrm{H})$ implies that the reaction was endothermic while positive value of entropy change $(\Delta S)$ implies an irregular increase in the randomness at the solid/solution interface of the adsorbent during the adsorption process.

\section{REFERENCES}

Abdus-salam, N. and Itiola, A.D.: Potential Application of Termite Mound for Adsorption and Removal of $\mathrm{Pb}(\mathrm{II})$ from aqueous Solutions. J. Iran chem. Soc. 9, 373-382 (2012).

Adegoke H. I., Adekola F. O., Fatoki O. S., and Ximba B.J.: Adsorption of Cr (VI) on synthetic Hematite nanoparticles of different morphologies. Korean journal of chemical engineering. 2(1): 142-154 (2014).

Ajmal, M., Rao, B., Ahmad, R. A., Ahmad, J.: Adsorption studies on Citrus reticulate (fruit peel of orange): Removal and recovery of Ni(II) from electroplating wastewater. J. Hazard. Mater. 79: 117-131 (2000).

Aloko, D. F., and Adebayo G. A.: Production and Characterization of Activated carbons from Agricultural waste. J. Eng. Applied Sci. 2(2), 440-444 (2008).

Amarasinghe, B. M., Williams, A. R.: Tea waste as a low cost adsorbent for the removal of $\mathrm{Cu}$ and $\mathrm{Pb}$ from wastewater. Chem. Eng. J. 132: 299-309 (2007).

Babarinde, N. A. A., Babalola, J. O., Adegoke, J., Muraizu, U., Ogunbanwo, T., Ogunjinrin, F.: Kinetic, equilibrium and thermodynamics studies of the biosorption of $\mathrm{Ni}(\mathrm{II}), \quad \mathrm{Cr}$ (III) and $\mathrm{Co}(\mathrm{II})$ from aqueous solutions using banana (Musa acuminata) leaf. Int. J. Phy. Sci. 7: 1376-1385 (2012b).

Babarinde, N. A. A.; Babalola, J. O.; Adegoke, J.; Osundeko A. O, .; Ibidapo, T.; Nwabugwu, C. A.; Ogundimu, O. F.: Kinetic, equilibrium and thermodynamics studies of the biosorption of $\mathrm{Ni}(\mathrm{II}), \mathrm{Cr}(\mathrm{III})$ and $\mathrm{Co}$ (II) from aqueous solutions using cocoyam (colocasia esculenta) leaf. pacific. J.of Sci.and tech. 13(2): 272-282 (2012a).

Badmus M. A. O, Audu, T. O. K, and Anyata B. U.: Removal of Lead ion from Industrial Waste waters by Activated carbon from Periwinkle shells. Turkish J. Env. Sci. 31: 251-263 (2007).

Bhatnagar, A.; Sillanp, M.: Utilization of agroindustrial and municipal waste materials as potential adsorbents for water treatment-a review. Chem. Eng. J. 24: 277-296 (2010).

Cay, S.; Uyanik, A.; Ozasik, A.: Single and binary component adsorption on copper(II) and cadmium(II) from aqueous solution using tea industry waste. Sep. Purif. Technol. 38: 273-280 (2004).

Chien, S.H., Clayton, W.R.: Application of Elovich equation to the kinetics of phosphate release and sorption on soils. Soil Sci. Am. J. 44, 265268 (1980).

Das B. and Mondal N. K.: Calcareous soil as new adsorbent to remove Lead from aqueous solution: Equilibrium, Kinetics and Thermodynamic Study. Universal J. Environs. Res. Tech, 1(4), 515-518 (2011).

Deng H. Li G., Yang H., Tang J., and Tang J.: Preparation of Activated carbons from cottonstalk by microwave assisted $\mathrm{KOH}$ and $\mathrm{K}_{2} \mathrm{CO}_{3}$ activation. Chem. Eng. Journal, 163, 373381 (2010).

Ekop A. S and Eddy, N. O.: Thermodynamic Study on the Adsorption of $\mathrm{Pb}^{2+}$ and $\mathrm{Zn}^{2+}$ from aqueous solution by human hair. E- journal of chemistry. 7(4), 1296- 1303 (2010).

Elaigwu S.E, Usman L.A, Awolola G.V, Adebayo G.B. and Ajayi R.M.K.: Adsorption of Pb (II) from aqueous solution by activated carbon prepared from cow dung Adv. In. Net. Applied Sci. 3(3), 442-446 (2009).

Elnasri N. A, Mutaz A. E, and Mohammed A. E.: Physico-chemical Characterization and Freundlich isotherms of Adsorption of $\mathrm{Fe}(\mathrm{II})$ from aqueous solution by using Activated carbon prepared from Doum fruit waste. Arch. Appl. Sci. Res, 5(5): 149- 158 (2013).

Fan M., Marshall W., Daugaard D., Brown C.: Steam activation of chars produced From oat hulls. Bioresource Technology. 93 (1):103-107 (2003).

Faust, S. D and Aly O. M.: Chemistry of water treatment; Butterworths Publishers: Boston, London Wellington, pp211 (1983).

Gan, Q., Allen, S., and Matthews, R.: Activation of waste MDF sawdust charcoal and its 
reactivedye adsorption characteristics. Waste Management, 24(2): 84-85 (2004).

Ho, Y. S.; McKay, G.: Pseudo-second order model for sorption process. Process Biochem. 34: 451-465 (2000).

Idris, S., Iyaka Y. A., Dauda B. E. N., Ndamitso M. $M$ and Umar M. T.: Kinetic Study of Utilizing Groundnut Shell as an Adsorbent in Removing Chromium and Nickel from dye effluent.

American chemical science journal. 2(1): 12-24 (2012)

Itodo, A.U., Abdulrahman, F.W., Hassan L.G., Maigandi, S.A., Happiness

U.O.:Thermodynamic, equilibrium, kinetics and adsorption mechanism of industrial dye removal by chemically modified poultry droppings activated carbon. Nigerian Journal of Basic and Applied Science; 17(1):38-43 (2009).

Itodo, A.U, Itodo, H.U., Atiku, F.A., Kolo, R.A., and Kwaido A.A.: Dyes Uptake onto Processed Raw Mango Seed back. Asian J. of Plant Sci. Res., 1(1), 57-66 (2011).

Jimoh, T. O. , Yisa, J., Ajai, A. I., Musa, A.: Kinetics and Thermodynamics Studies of the Biosorption of $\mathrm{Pb}(\mathrm{II}), \mathrm{Cd}(\mathrm{II})$ and $\mathrm{Zn}(\mathrm{II})$ Ions from Aqueous Solution by Sweet Orange (Citrus sinensis) Seeds. International Journal of Modern Chemistry. 4(1): 19-37 (2013).

Jimoh, T. O., Buoro, A. T. and Muriana, M.: Utilization of Blighia sapida (Akee apple) pod in the removal of lead, cadmium and cobalt ions from aqueous solution. Journal of Environmental Chemistry and Ecotoxicology . 4(10), 178- 187 (2012).

Jimoh, T.; Egila, J. N.; Dauda, B. E. N.; Iyaka, Y. A.: Pre-concentration and removal of heavy metal ions from aqueous solution using modified charcoal. J. Environ.Chem.Ecotoxicol. 3(9): 238243 (2011).

Kirby, B. J.: Micro and Nanoscale Fluid Mechanics: Transport in Microfluidic Devices. 3(2), 76-77 (2010).

Kobya, M. E. Demirbas, E. Senturk, M. I.: Adsorption of Heavy metal ions from aqueous solutions by activated carbon prepared from apricot stone. Bioresources Technology, 96: 1518-1521 (2005)

Krishnan, K. A.; Anirudhan, T. S.: Removal of cadmium(II) from aqueous solutions by steamactivated sulphurised carbon prepared from sugar cane bagasse pith: Kinetics and equilibrium studies. Water SA, 29(2):147-156 (2003).

Langmuir I.: The adsorption of gases in plane surfaces of glass, mica and Platinum. J. American Chem. Society. 40, 1361-1403 (1918).

Lillo-Rodenas M.A., Cazorla Amoros, D., LinaresSolono, A.: Behaviour of Activated carbons with different pore size distribution and surface oxygen groups for Benzene and Toluene Adsorption at low concentration carbon. Afr. J. Biotechnol. 43; 1758-1767 (2003).

Mane, S. W., Vanjara, A. K and Sawant, M. R.: Removal of Phenol from Wastewater using Date seed carbon. Journal of the Chinese Chemical Society. 52, 1117-1122 (2005).

Mishra, S. Prakash, D. J., and Ramakrishna, G.: Characterization and Utilization of Mahua oil cake- A new adsorbent for the removal of Congo red Dye from Aqueous phase. Elect. J. Env. Agric. Food chemistry. 8, 425-436 (2009).

Mohan, D., and Singh, K.P.: Single component and multicomponent Adsorption of cadmium and zinc using activated carbon derived from baesse: agricultural waste. Water Res. 36: 2304-2318 (2002).

Najua, D.T., Luqman, C.Z., Zawani, S.A.: Adsorption of copper from aqueous solution by Elais Guineensis Kernel activated carbon. Journal of Engineering Sci. \& Tech. (5)180-189 (2008)..

Okeimen, F. E.; Onyenkpa, V. U.: Binding of cadmium, copper, lead and nickel ions with melon (Citrullus vulgaris) seed husk. Biol. Waste. 29: 11-16 (2000).

Onundi, Y. B., Mamun, A. A, Al-Khatib, M. F., AlSaadi. M. A. and Suleyman, A. M. Heavy metals Removal from Synthetic Wastewater by a novel nano-size composite adsorbent. Int. J. Environ. Sci. Tech. 8(4): 799-806 (2011).

Raffiea, B. J., Palanisamy, P. N and Sivakumar, P.: Preparation and Characterization of Activated carbon from thevetia peruviana for the removal of dyes from textile waste water. Advances in Applied Science Research, 3(1), 377-383 (2012).

Renuga, D. N.; Manjusha, K.; Lalitha, P.: Removal of hexavalent chromium fromaqueous solution using an eco-friendly activated carbon adsorbent. Pelagia Library Adv. Appl. Sci. Res, 1: 247-254 (2010). 
Sahu J. N., Achrya J. and Meikap, B. C.: Optimization of Production conditions for activated carbons from Tamarind wood by zinc chloride using response surface methodology. Bioresource Technology. 101: 1974-1982 (2010).

Salman, M., Athar, M. Shafique, U., Din, M. I., Rehman, R., Akram, A. and Ali, S. Z.: Adsorption Modelling of Alizarin Yellow on Untreated and Treated charcoal.Turkish J. Eng. Env. Sci. 35, 209-216 (2011).

Selvaraj, K.; Manonmani, S.; Pattabhi, S.: Removal of hexavalent chromium using distillery sludge. Bioresour. Technol. 89: 207-211 (2003).

Sheng, P.X., Ting Y-P, Chen J.P., Hong L.: Sorption of lead, copper, cadmium, zinc and nickel by marine algal biomass: characterization of biosorptive capacity and investigation of mechanisms. J. Colloid Interface Sci. 275 (1): 131-141 (2004).

Sparks, D.L.: Kinetic of reaction in pure and mixed systems, in soil physical chemistry. CRC Press, Boca Raton. pp34-66 (1986).

Strinivassan, S.K., Tyagi, R., and Pant, N.: Adsorption of heavy metal ions on carbonaceous material developed from the waste slurry generated in local fertilizer plant. J. Water Resources. (23) 111-161 (1999).
Sugunadevi, S.R., Sathishkumar, M., Shanthi, K., Kadiruvelu, K. and Pattabhi S.: The adsorption of $\mathrm{Cd}(\mathrm{II})$ ions on sulphuric acid treated wheat bran. J. Hazard. Mater. 137(2): 849-855 (2002).

Viboon, S., Chiravoot, P., Duangdao, A. and Duangduen, A.: Preparation and Characterization of activated carbon from the pyrolysis of physic nut (jatropha curcas L.) waste. J. American Chem. Society. 3(2): 133-137 (2007).

Vimonses, V., Lei, S., Jin, B., Chow, C. W. K., Saint, C.: Kinetic study and equilibrium analysis of Congo red adsorption by clay materials. Chem. Eng. J148: 354-364 (2009).

Wasewar, K. L., Mohammad, A., Prasad, B., Mishra, I. M.: Batch adsorption of $\mathrm{Zn}$ (II) ion using tea factory waste as an adsorbent. Desalination, 244: 66-71 (2009).

Yang, T. and Lua A.: Characteristics of activated carbons prepared from pistachio-nut shells by physical activation. Journal of Colloid and Interface Science. 267, 408-417 (2003). 